\title{
Morphologic and Cytochemical Characteristics of the Blood Cells of the Yellow-Bellied Slider (Trachemys scripta scripta)
}

\author{
J. D. Hernández ${ }^{1,2}$, P. Castro ${ }^{1}$, P. Saavedra ${ }^{3}$, P. Ramírez ${ }^{2}$ and J. Orós ${ }^{1 *}$ \\ Addresses of authors: ${ }^{1}$ Unit of Veterinary Histology, Veterinary Faculty, University of Las Palmas de Gran Canaria (ULPGC), 35413 Arucas, \\ Las Palmas, Spain; \\ 2 Serviexotic, 35320 Vega de San Mateo, Las Palmas, Spain; \\ 3 School of Medicine, University of Las Palmas de Gran Canaria (ULPGC), 35016 Las Palmas de Gran Canaria, Spain
}

\begin{abstract}
*Correspondence:
Tel.: (+34) 928 454375;

fax: $(+34) 928457431$;

e-mail: jorge.oros@ulpgc.es
\end{abstract}

With 7 figures and 2 tables

Received March 2016; accepted for publication July 2017

doi: 10.1111/ahe.12289

\begin{abstract}
Summary
The increasing prevalence of yellow-bellied sliders (Trachemys scripta scripta) as pets in the European Union and also its utilization as animal models for experimental purposes makes crucial an accurate classification of their blood cells. The aim of this work was to provide a morphologic classification based on the cytochemical characteristics of the blood cells of 15 yellow-bellied sliders. Cytochemical stains included benzidine peroxidase, chloroacetate esterase, alphanaphthyl butyrate esterase (with and without sodium fluoride), acid phosphatase (with and without tartaric acid), Sudan black B, periodic acid-Schiff and toluidine blue. Nuclear and cellular dimensions were also measured based on quick Romanowsky-type stained smears. Besides erythrocytes and thrombocytes, five types of white blood cells were identified: heterophils, eosinophils, basophils, lymphocytes and monocytes. The cytochemical patterns of heterophils, eosinophils and basophils were unique compared to those described for other chelonians. This paper provides a useful guideline for clinical settings and further haematological studies of this species.
\end{abstract}

\section{Introduction}

The increasing importance of reptiles as pets makes crucial a better knowledge of their anatomic and physiologic characteristics. That includes a complete description and characterization of the blood cells and the establishment of their normal haematological parameters. However, the classification of blood cells in reptiles is controversial because cellular lineages are uncertain and/or variable criteria have been used to categorize cells (Work et al., 1998). That is why recent studies on reptiles have incorporated cytochemical staining techniques and electron microscopy to obtain more homogenous and accurate results (Work et al., 1998; Martínez-Silvestre et al., 2005; Salakij et al., 2002, 2014). Even though, many reptile haematological aspects remain unknown and many species have not been subject to proper and structured studies.

The blood cells of several clinically uncommon freshwater turtles have been cytochemically characterized
(Azevedo and Lunardi, 2003; Chung et al., 2009; Chansue et al., 2011). However, although the ultrastructural characteristics of blood cells of yellow-bellied slider turtles (Trachemys scripta scripta) have been recently described (Hernández et al., 2016), no previous cytochemical characterization of blood cells of turtles of the genus Trachemys has been reported.

The yellow-bellied slider (Trachemys scripta scripta Schoepff, 1792) is a chelonian belonging to the suborder Cryptodira and to the family Emydidae. The Trachemys genus includes 15 species, all of them distributed by the American continent, bound to freshwater environments. The species Trachemys scripta includes three different but closely related subspecies (T. scripta elegans, T. scripta scripta and T. scripta troostii), being all of them semiaquatic and mainly carnivorous/omnivorous (Ernst and Barbour, 1989; Frank and Ramus, 1995; Boyer and Boyer, 2006; Fritz and Havas, 2007). The yellow-bellied slider is native to the southeastern United States (Fritz and Havas, 2007). 
The classification of blood cells from the yellow-bellied slider is relevant mainly given: (1) the increasing prevalence of these reptiles as pets and as patients at the veterinary hospitals around the world due to the ban on the import of red-eared sliders (Trachemys scripta elegans) into the European Union as a potentially invasive species, after which the pet turtle farming industry partly shifted to T. scripta scripta (IUCN, 2017); and (2) the recent and intensive study of both subspecies in captivity in clinical settings and research trials ( $\mathrm{Li}$ et al., 2010; Guirlet and Das, 2012; Mans et al., 2012; Allender et al., 2013; Krivoruchko and Storey, 2013; Joyce and Wang, 2014; Kitana and Callard, 2014).

This paper provides a cytochemically-based morphological classification of the blood cells of the yellow-bellied slider (Trachemys scripta scripta) as a useful reference for clinical settings and haematological studies of this species.

\section{Materials and Methods}

\section{Animals}

Seven male and eight female adult yellow-bellied sliders (mean straight carapace length, SCL: $15.79 \pm 4.36 \mathrm{~cm}$; mean weight: $0.83 \pm 0.56 \mathrm{~kg}$ ) were used. All the specimens were obtained from private collections from Gran Canaria Island; turtles had been maintained in outdoor facilities under natural conditions and fed mainly with commercial diets. The animals were treated according to the guidelines specified by the Spanish Ministry of Agriculture, Food and Environment and under the control of the ethical commission of Veterinary Medicine of the University of Las Palmas de Gran Canaria (agreement MV-2014/06).

\section{Blood obtaining and cytochemical stains}

Blood samples $(0.5 \mathrm{ml})$ were collected from the dorsal coccygeal vein, avoiding the extraction of lymphatic liquid and discarding the contaminated samples (LópezOlvera et al., 2003; Innis et al., 2007). Anti-coagulants were not used to avoid altering cell morphology or staining properties (Muro et al., 1998). Blood smears were prepared immediately after blood collection and air-dried. Two blood smears of each turtle were stained with a quick Romanowsky-type stain (Diff-Quick, Panreac Química SAU, Barcelona, Spain; Casal and Orós, 2007). For each turtle, twenty erythrocytes and at least ten of each other cell type were measured (area, perimeter, maximum length and minimum length) using an image analysis program (Image-Pro Plus Software v4.5, Media Cybernetics, Rockville, MD, USA).
Two blood smears from each turtle were also stained with the following cytochemical stains: benzidine peroxidase (PER), chloroacetate esterase (CAE), alpha-naphthyl butyrate esterase with sodium fluoride (NBEF) and without sodium fluoride (NBENF), acid phosphatase with tartaric acid (ACPT) and without tartaric acid (ACPNT), Sudan black B (SBB), periodic acid-Schiff (PAS) and toluidine blue (TB; Casal and Orós, 2007), using commercial kits (Sigma-Aldrich Inc., St Louis, MO, USA) and following the protocols given by the manufacturers except for NBEF (Vives and Aguilar, 1988) and TB (Caballero et al., 1993). Healthy human blood smears were used as controls to ensure that the staining procedure was performed correctly.

\section{Statistical analysis}

The means and standard deviations (SD) of the cell dimensions and a mixed-effect model that compared the cells between the sexes (Laird and Wäre, 1982) were obtained using $\mathrm{R}$ statistical software, version 3.1.0 (R Development Core Team, Vienna, Austria).

\section{Results}

Dimensions of the blood cells for both sexes of yellowbellied sliders are shown in Table 1

Erythrocytes were oval with a pale blue-purple cytoplasm and a dark violet-blue oval or round nucleus. Immature erythrocytes had a more rounded shape, bigger nucleus and increased cytoplasmic basophilia. Immature erythrocytes were typically smaller than mature ones, but the size depended on the maturation stage of the cell. Some erythrocytes had small basophilic intracytoplasmic inclusions, usually a single inclusion near the nucleus. Erythrocytes were positive for PAS (Fig. 1), NBE (with and without sodium fluoride) and ACP (with and without tartaric acid; Table 2).

Heterophils were round cells with an eccentric, dark purple oval or round nucleus with clumped chromatin. Some heterophils had a lobulated nucleus. The abundant cytoplasm was filled with eosinophilic and fusiform or pleomorphic granules (Fig. 2). Heterophils were positive for all the cytochemical stains except TB (Table 2, Fig. 3).

Eosinophils were very similar to heterophils in shape and size, with an eccentric, purple oval or round nucleus with clumped chromatin. The cytoplasm was pale pink to weak purple, with a moderate number of small round pink-red granules (Fig. 4a). These cells were positive for ACP (with and without tartrate; Fig. 4b), NBE (without sodium fluoride), CAE and PAS and moderately positive for SBB (Table 2). 
Table 1. Mean and standard deviation, separated by sex, of the dimensions of the blood cells of yellow-bellied sliders (Trachemys scriptas cripta) on blood smears (all dimensions are shown in $\mu \mathrm{m}$, except area, in $\mu \mathrm{m}^{2}$ )

\begin{tabular}{|c|c|c|c|c|c|}
\hline Cell & Variable & Global $n=15$ & Males $n=7$ & Females $n=8$ & $P$ \\
\hline \multirow[t]{8}{*}{ Erythrocytes } & Maximum length cytoplasmic ${ }^{a}$ & $18.42 \pm 1.53$ & $18.49 \pm 1.53$ & $18.36 \pm 1.52$ & .731 \\
\hline & Maximum length nuclear ${ }^{a}$ & $5.45 \pm 0.47$ & $5.52 \pm 0.43$ & $5.38 \pm 0.49$ & .329 \\
\hline & Minimum length cytoplasmic ${ }^{a}$ & $11.46 \pm 0.95$ & $11.51 \pm 0.97$ & $11.78 \pm 0.91$ & .393 \\
\hline & Minimum length nuclear ${ }^{a}$ & $4.57 \pm 0.39$ & $4.58 \pm 0.40$ & $4.55 \pm 0.38$ & .806 \\
\hline & Cytoplasmic area & $176.9 \pm 22.47$ & $175.6 \pm 22.4$ & $178.2 \pm 22.53$ & .696 \\
\hline & Nuclear area & $19.97 \pm 2.84$ & $20.35 \pm 2.77$ & $19.64 \pm 2.87$ & .498 \\
\hline & Cytoplasmic perimeter & $48.43 \pm 3.31$ & $48.42 \pm 3.25$ & $48.45 \pm 3.38$ & .971 \\
\hline & Nuclear Perimeter & $15.86 \pm 1.22$ & $16.04 \pm 1.22$ & $15.70 \pm 1.20$ & .416 \\
\hline \multirow[t]{8}{*}{ Heterophils } & Maximum length cytoplasmic ${ }^{a}$ & $12.41 \pm 1.94$ & $12.26 \pm 2.25$ & $12.54 \pm 1.63$ & .751 \\
\hline & Maximum length nuclear ${ }^{\mathrm{a}}$ & $7.61 \pm 0.9$ & $7.65 \pm 0.95$ & $7.58 \pm 0.85$ & .633 \\
\hline & Minimum length cytoplasmic ${ }^{a}$ & $11.36 \pm 1.73$ & $11.28 \pm 1.94$ & $11.43 \pm 1.54$ & .857 \\
\hline & Minimum length nuclear ${ }^{a}$ & $4.95 \pm 0.99$ & $4.83 \pm 1.13$ & $5.05 \pm 0.84$ & .319 \\
\hline & Cytoplasmic area & $113.2 \pm 33.47$ & $111.8 \pm 38.21$ & $114.5 \pm 28.95$ & .875 \\
\hline & Nuclear area & $29.19 \pm 7.59$ & $28.60 \pm 8.62$ & $29.71 \pm 6.59$ & .498 \\
\hline & Cytoplasmic perimeter & $37.48 \pm 5.66$ & $37.13 \pm 6.55$ & $37.79 \pm 4.77$ & .804 \\
\hline & Nuclear Perimeter & $19.96 \pm 2.41$ & $19.83 \pm 2.68$ & $20.08 \pm 2.16$ & .619 \\
\hline \multirow[t]{8}{*}{ Eosinophils } & Maximum length cytoplasmic ${ }^{a}$ & $13.56 \pm 1.54$ & $13.28 \pm 1.34$ & $13.80 \pm 1.66$ & .412 \\
\hline & Maximum length nuclear ${ }^{a}$ & $7.57 \pm 1.11$ & $7.62 \pm 1.16$ & $7.53 \pm 1.07$ & .757 \\
\hline & Minimum length cytoplasmic ${ }^{a}$ & $11.62 \pm 1.32$ & $11.92 \pm 1.41$ & $11.36 \pm 1.18$ & .251 \\
\hline & Minimum length nuclear ${ }^{a}$ & $4.76 \pm 1.12$ & $4.55 \pm 1.09$ & $4.95 \pm 1.11$ & .413 \\
\hline & Cytoplasmic area & $123.8 \pm 22.5$ & $126.6 \pm 25.34$ & $121.3 \pm 19.46$ & .531 \\
\hline & Nuclear area & $28.39 \pm 8.1$ & $27.53 \pm 8.09$ & $29.15 \pm 8.09$ & .648 \\
\hline & Cytoplasmic perimeter & $39.9 \pm 3.66$ & $40.04 \pm 3.85$ & $39.78 \pm 3.49$ & .856 \\
\hline & Nuclear Perimeter & $20.0 \pm 2.99$ & $19.77 \pm 3.19$ & $20.21 \pm 2.80$ & .738 \\
\hline \multirow[t]{8}{*}{ Basophils } & Maximum length cytoplasmic ${ }^{a}$ & $8.69 \pm 0.98$ & $8.68 \pm 1.03$ & $8.70 \pm 0.93$ & .942 \\
\hline & Maximum length nuclear ${ }^{\mathrm{a}}$ & $6.33 \pm 0.88$ & $6.29 \pm 0.84$ & $6.36 \pm 0.91$ & .804 \\
\hline & Minimum length cytoplasmic ${ }^{a}$ & $7.89 \pm 0.84$ & $7.86 \pm 0.88$ & $7.92 \pm 0.82$ & .820 \\
\hline & Minimum length nuclear ${ }^{a}$ & $5.63 \pm 0.88$ & $5.62 \pm 0.85$ & $5.65 \pm 0.90$ & .933 \\
\hline & Cytoplasmic area & $54.39 \pm 11.54$ & $54.51 \pm 11.90$ & $54.28 \pm 11.27$ & .965 \\
\hline & Nuclear area & $29.06 \pm 8.03$ & $28.72 \pm 7.79$ & $29.37 \pm 8.27$ & .804 \\
\hline & Cytoplasmic perimeter & $26.16 \pm 2.81$ & $26.16 \pm 2.94$ & $26.15 \pm 2.71$ & .987 \\
\hline & Nuclear Perimeter & $18.82 \pm 2.64$ & $18.73 \pm 2.53$ & $18.90 \pm 2.74$ & .864 \\
\hline \multirow[t]{8}{*}{ Lymphocytes } & Maximum length cytoplasmic ${ }^{a}$ & $9.25 \pm 1.33$ & $9.00 \pm 1.21$ & $9.47 \pm 1.39$ & $.032^{b}$ \\
\hline & Maximum length nuclear ${ }^{\mathrm{a}}$ & $8.05 \pm 0.95$ & $7.83 \pm 0.94$ & $8.24 \pm 0.92$ & .062 \\
\hline & Minimum length cytoplasmic ${ }^{a}$ & $8.04 \pm 0.99$ & $7.97 \pm 0.96$ & $8.11 \pm 1.01$ & .501 \\
\hline & Minimum length nuclear ${ }^{a}$ & $6.84 \pm 0.83$ & $6.74 \pm 0.89$ & $6.93 \pm 0.76$ & .226 \\
\hline & Cytoplasmic area & $58.21 \pm 13.62$ & $55.99 \pm 13.06$ & $60.20 \pm 13.87$ & .109 \\
\hline & Nuclear area & $43.89 \pm 9.58$ & $42.08 \pm 10.13$ & $45.50 \pm 8.81$ & .107 \\
\hline & Cytoplasmic perimeter & $27.67 \pm 3.42$ & $26.67 \pm 3.24$ & $27.80 \pm 3.50$ & $.046^{\mathrm{b}}$ \\
\hline & Nuclear Perimeter & $23.62 \pm 2.64$ & $23.03 \pm 2.66$ & $24.15 \pm 2.53$ & .055 \\
\hline \multirow[t]{8}{*}{ Monocytes } & Maximum length cytoplasmic ${ }^{a}$ & $12.57 \pm 1.63$ & $12.48 \pm 1.54$ & $12.65 \pm 1.70$ & .558 \\
\hline & Maximum length nuclear ${ }^{\mathrm{a}}$ & $9.58 \pm 1.04$ & $9.39 \pm 0.95$ & $9.74 \pm 1.10$ & .252 \\
\hline & Minimum length cytoplasmic ${ }^{a}$ & $10.59 \pm 1.23$ & $10.51 \pm 1.16$ & $10.66 \pm 1.29$ & .494 \\
\hline & Minimum length nuclear ${ }^{a}$ & $7.08 \pm 0.82$ & $6.92 \pm 0.82$ & $7.22 \pm 0.81$ & .101 \\
\hline & Cytoplasmic area & $104.3 \pm 21.87$ & $103.65 \pm 20.99$ & $104.87 \pm 22.72$ & .796 \\
\hline & Nuclear area & $53.64 \pm 8.97$ & $51.84 \pm 8.78$ & $55.21 \pm 8.89$ & .153 \\
\hline & Cytoplasmic perimeter & $36.57 \pm 4.0$ & $36.23 \pm 3.67$ & $36.96 \pm 4.27$ & .427 \\
\hline & Nuclear Perimeter & $27.04 \pm 2.73$ & $26.43 \pm 2.30$ & $27.57 \pm 2.98$ & .187 \\
\hline \multirow[t]{8}{*}{ Standard thrombocytes } & Maximum length cytoplasmic ${ }^{a}$ & $15.08 \pm 2.31$ & $14.80 \pm 2.33$ & $15.43 \pm 2.26$ & .479 \\
\hline & Maximum length nuclear ${ }^{a}$ & $8.96 \pm 0.9$ & $9.08 \pm 0.79$ & $8.82 \pm 1.02$ & .305 \\
\hline & Minimum length cytoplasmic ${ }^{a}$ & $5.76 \pm 0.82$ & $5.76 \pm 0.83$ & $5.76 \pm 0.82$ & .971 \\
\hline & Minimum length nuclear ${ }^{a}$ & $4.43 \pm 0.53$ & $4.44 \pm 0.57$ & $4.42 \pm 0.48$ & .870 \\
\hline & Cytoplasmic area & $71.15 \pm 16.55$ & $70.62 \pm 17.93$ & $71.79 \pm 14.89$ & .889 \\
\hline & Nuclear area & $32.97 \pm 5.47$ & $33.57 \pm 5.67$ & $32.25 \pm 5.20$ & .513 \\
\hline & Cytoplasmic perimeter & $35.4 \pm 4.91$ & $34.75 \pm 4.97$ & $36.19 \pm 4.78$ & .449 \\
\hline & Nuclear Perimeter & $22.23 \pm 1.89$ & $22.46 \pm 1.72$ & $21.95 \pm 2.05$ & .416 \\
\hline
\end{tabular}


Table 1. (continued)

\begin{tabular}{|c|c|c|c|c|c|}
\hline Cell & Variable & Global $n=15$ & Males $n=7$ & Females $n=8$ & $P$ \\
\hline \multirow[t]{8}{*}{ Pleomorphic thrombocytes } & Maximum length cytoplasmic ${ }^{a}$ & $7.31 \pm 1.02$ & $7.28 \pm 1.05$ & $7.33 \pm 1.00$ & .829 \\
\hline & Maximum length nuclear ${ }^{a}$ & $6.30 \pm 0.76$ & $6.30 \pm 0.80$ & $6.29 \pm 0.73$ & .929 \\
\hline & Minimum length cytoplasmic ${ }^{a}$ & $5.82 \pm 830$ & $5.72 \pm 0.72$ & $5.90 \pm 0.91$ & .449 \\
\hline & Minimum length nuclear ${ }^{a}$ & $5.01 \pm 0.67$ & $4.96 \pm 0.66$ & $5.04 \pm 0.68$ & .723 \\
\hline & Cytoplasmic area & $33.19 \pm 7.66$ & $32.36 \pm 7.08$ & $33.91 \pm 8.11$ & .473 \\
\hline & Nuclear area & $24.94 \pm 5.13$ & $24.64 \pm 5.08$ & $25.20 \pm 5.19$ & .759 \\
\hline & Cytoplasmic perimeter & $20.83 \pm 2.54$ & $20.61 \pm 2.46$ & $21.02 \pm 2.61$ & .579 \\
\hline & Nuclear Perimeter & $17.97 \pm 1.92$ & $17.88 \pm 1.99$ & $18.04 \pm 1.86$ & .836 \\
\hline
\end{tabular}

a Diameter.

${ }^{\mathrm{b}} \mathrm{A}$ difference between males and females was considered significant when $P<0.05$.

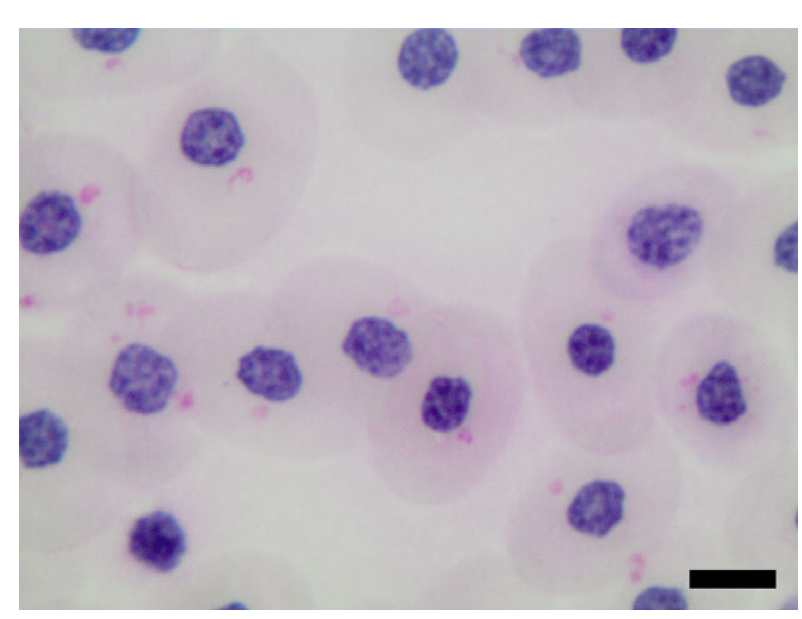

Fig. 1. Several Trachemys scripta scripta erythrocytes showing small PAS-positive inclusions. Bar $=9.2 \mu \mathrm{m}$.

Basophils were smaller than heterophils and eosinophils and they were round with a central-to-eccentric rounded nucleus. The usually scarce cytoplasm contained numerous round basophilic granules of different sizes, which often masked the nucleus. Basophils were positive for TB (Fig. 5), PAS, CAE and weakly positive for ACP (with and without tartrate). Basophils showed metachromatic granules after NBE staining (with and without sodium fluoride; Table 2).

Lymphocytes ranged from small to medium-large sized cells, with a rounded shape and a round purple-blue nucleus containing highly clumped chromatin. The scant, pale blue cytoplasm surrounded the nucleus (Fig. 6a). The visually estimated nucleus:cytoplasm area ratio was 0.75. Proportionally, bigger lymphocytes had more cytoplasm than smaller ones, and some of the measurements were bigger in females than in males (Table 1). Lymphocytes were positive for ACP (with and without tartrate) and weakly positive for NBE (with and without sodium fluoride), CAE and PAS (Table 2).
Table 2. Cytochemical staining characterization of blood cells of yellow-bellied sliders (Trachemys scripta scripta)

\begin{tabular}{|c|c|c|c|c|c|c|c|c|c|}
\hline \multirow[b]{3}{*}{ Blood cell } & \multicolumn{9}{|c|}{ Cytochemical stains } \\
\hline & \multicolumn{2}{|c|}{$A C P^{a}$} & \multirow[b]{2}{*}{ PER } & \multicolumn{2}{|c|}{$\mathrm{NBE}^{\mathrm{b}}$} & \multirow[b]{2}{*}{ CAE } & \multirow[b]{2}{*}{ SBB } & \multirow[b]{2}{*}{ PAS } & \multirow[b]{2}{*}{ TB } \\
\hline & $\mathrm{T}$ & NT & & $\mathrm{F}$ & NF & & & & \\
\hline Erythrocyte & $+1-$ & $+1-$ & $+1-$ & - & $+1-$ & - & - & $+1-$ & - \\
\hline Heterophil & + & + & + & + & + & + & + & + & - \\
\hline Eosinophil & + & + & - & - & + & + & \pm & + & - \\
\hline Basophil & \pm & \pm & - & + & + & + & - & + & + \\
\hline Lymphocyte & + & + & - & \pm & \pm & \pm & - & \pm & - \\
\hline Monocyte & + & + & - & - & + & + & - & + & - \\
\hline Thrombocyte & - & - & - & + & + & - & - & + & - \\
\hline
\end{tabular}

$A C P$, acid phosphatase; PER, benzidine peroxidase; NBE, alphanaphthyl butyrate esterase; $C A E$, chloroacetate esterase; SBB, Sudan black B; PAS, periodic acid-Schiff; TB, toluidine blue.

+ , positive; -, negative; \pm , moderately positive; + /-, some positive, some negative.

${ }^{\mathrm{a}}$ Two ACP stains were made. (T): with tartaric acid and (NT): without tartaric acid.

${ }^{\mathrm{b}}$ Two NBE stains were made. (F): with sodium fluoride and (NF): without sodium fluoride.

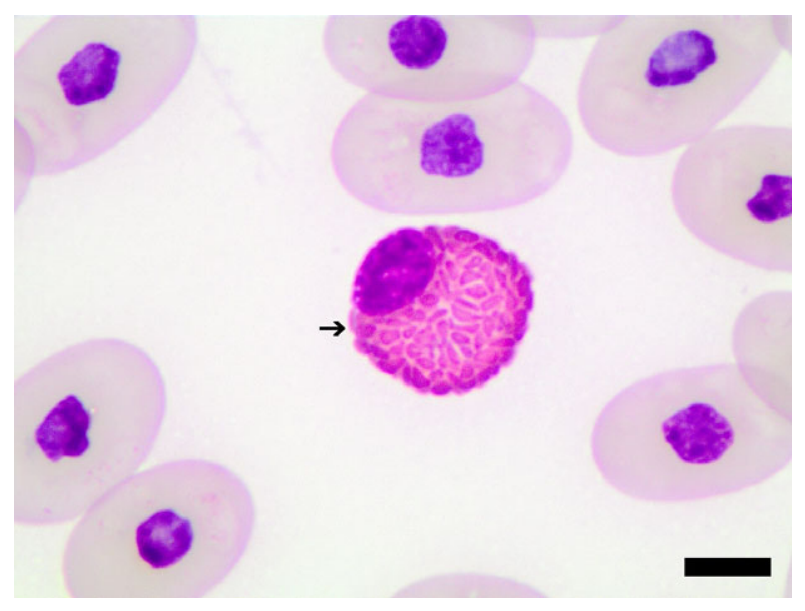

Fig. 2. Heterophil (arrow) of T. scripta scripta stained with Diff-Quick. Note the fusiform/pleomorphic eosinophilic granules. Bar $=7.8 \mu \mathrm{m}$. 

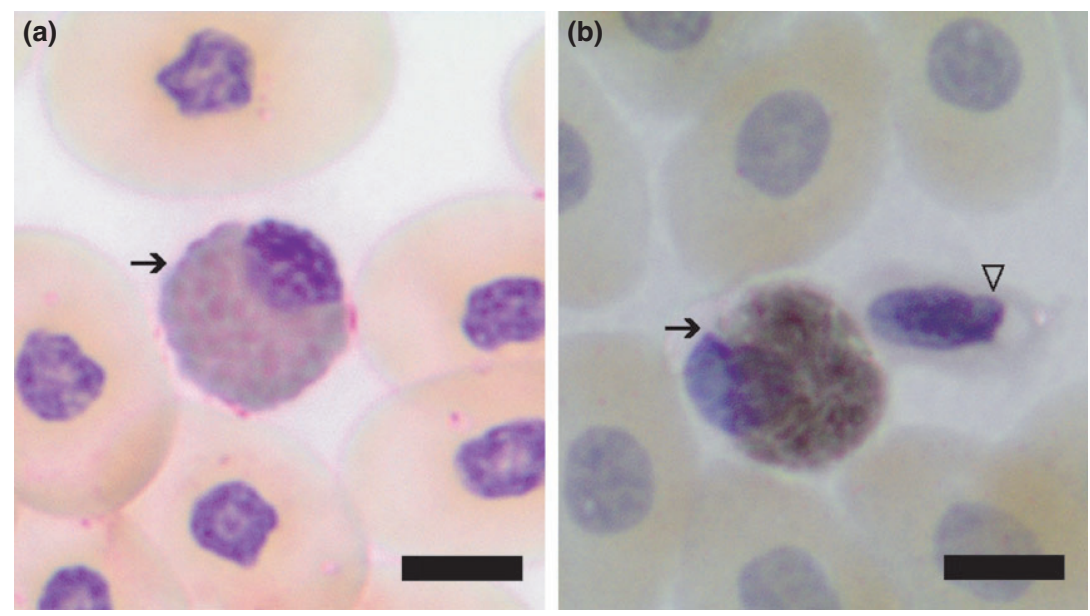

Fig. 3. (a) Heterophil (arrow) of T. scripta scripta showing positive chloroacetate esterase stain. Bar $=7.8 \mu$ m. (b) Heterophil (arrow) of $T$. scripta scripta showing positive Sudan black B stain closely to a thrombocyte (arrowhead) not stained. Bar $=6.5 \mu \mathrm{m}$.
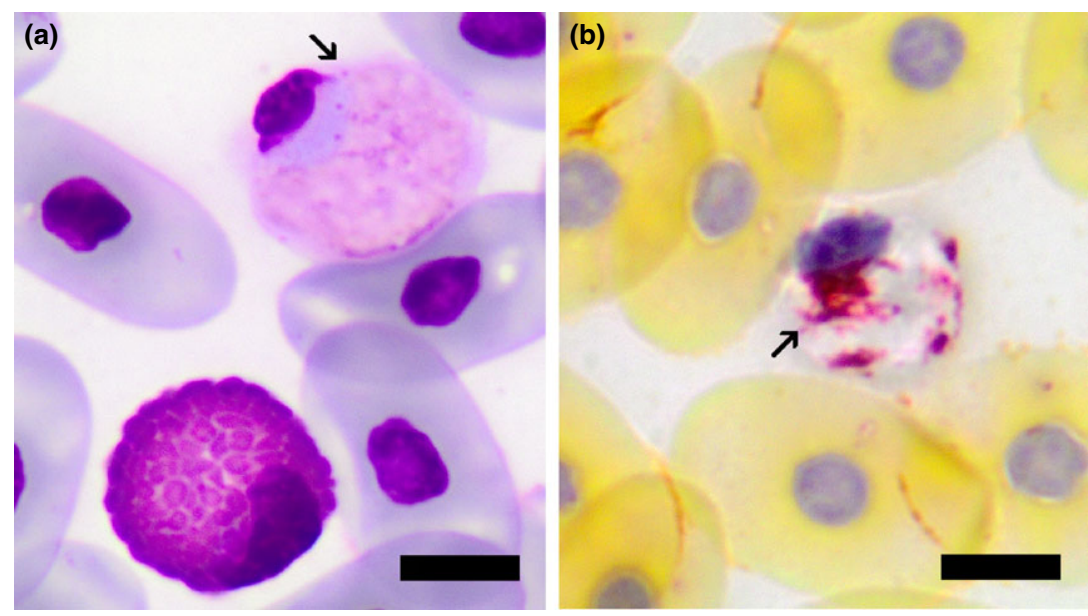

Fig. 4. (a) Eosinophil (arrow) of T. scripta scripta stained with Diff-Quick. Note the cytoplasmic tinny pink granules. Bar $=7.8 \mu \mathrm{m}$. (b) Eosinophil (arrow) showing positive acid phosphatase without tartaric acid stain. Bar $=9.2 \mu \mathrm{m}$.

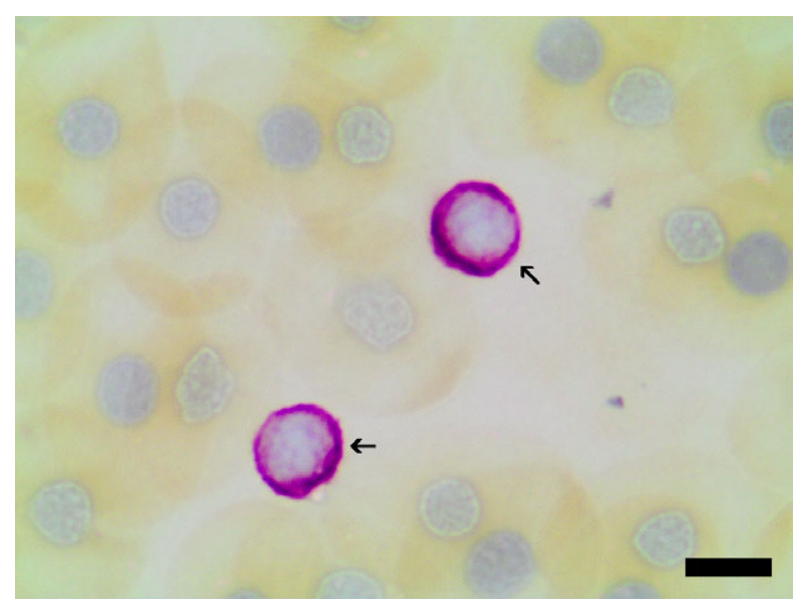

Fig. 5. Two basophils (arrows) of $T$. Scripta scripta showing positive toloudine blue stain. Bar $=6.9 \mu \mathrm{m}$.
Monocytes were bigger than lymphocytes, very often being round. The nuclei were purple-blue, with a less clumped chromatin pattern than in lymphocytes, and frequently fusiform, kidney-like or indented. The cytoplasm, which was more abundant than in lymphocytes, was pale blue and sometimes contained tiny basophilic and eosinophilic granules (Fig. 6b). The visually estimated nucleus:cytoplasm area ratio was approximately 0.5 . Monocytes were positive for ACP (with and without tartrate), NBE (without sodium fluoride, CAE and PAS; Table 2).

In this study, two types of thrombocytes were identified: standard thrombocytes and pleomorphic or reactive thrombocytes. Standard thrombocytes had an oval shape, with an oval dark violet-blue nucleus with clumped chromatin. Pleomorphic thrombocytes were rounded and small, with a rounded and more basophilic nucleus. The cytoplasm was pale blue, sometimes transparent, and 

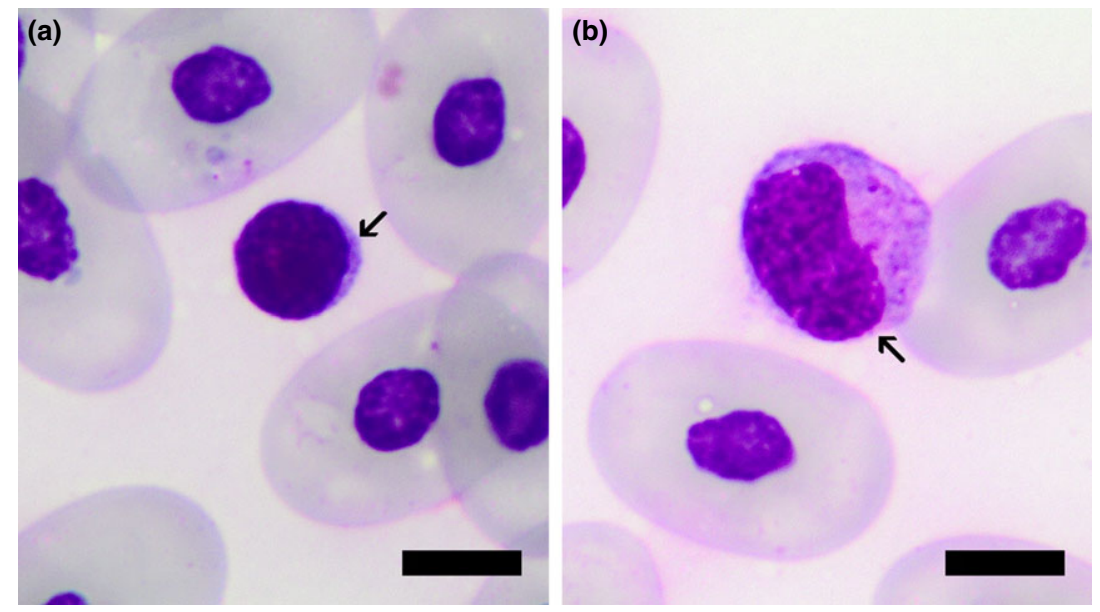

Fig. 6. (a) Small lymphocyte (arrow) of $T$. scripta scripta stained with Diff-Quick. Note the scarce blue cytoplasm. Bar $=7.3 \mu \mathrm{m}$. (b) Monocyte (arrow) of $T$. scripta scripta stained with Diff-Quick. Note the presence of eosinophilic and basophilic dust-like granules in the cytoplasm. Bar $=6.1 \mu \mathrm{m}$.
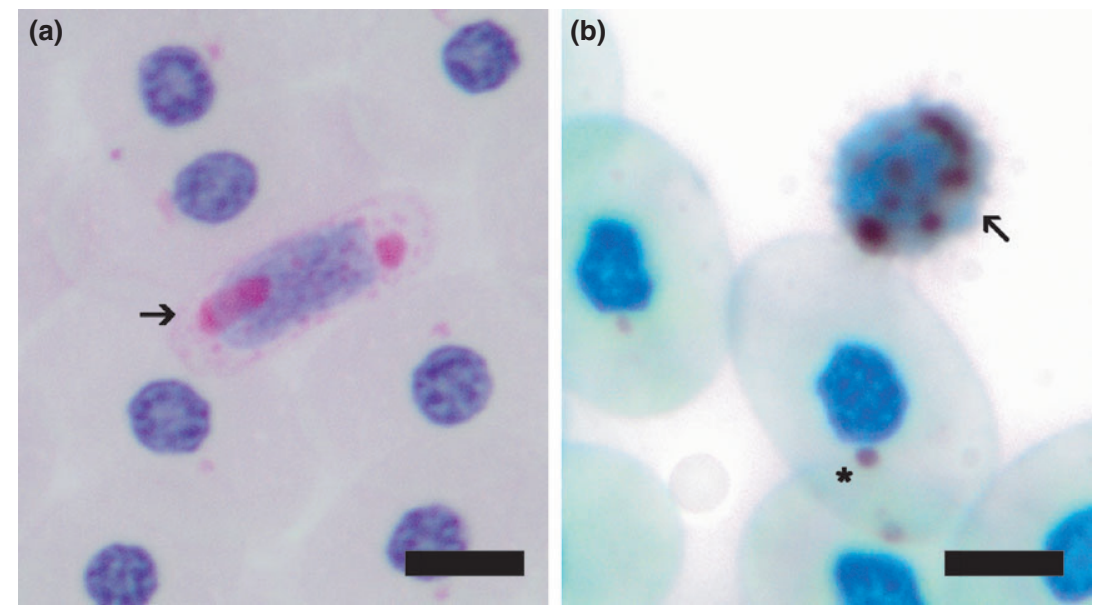

Fig. 7. (a) Thrombocyte (arrow) of T. scripta scripta showing positive periodic acid-Schiff stain. Note that the main staining is concentrated in the nuclear edges. Bar $=7.8 \mu \mathrm{m}$. (b) Pleomorphic thrombocyte (arrow) of $T$. scripta scripta showing positive alpha-naphthyl butirate esterase (without sodium fluoride) stain. Note the presence of an erythrocyte with a positive inclusion (*). Bar $=6.9 \mu \mathrm{m}$.

scarce in the pleomorphic thrombocytes. In the elongated forms, the cytoplasm showed rounded and refractive structures, possibly vacuoles, at both sides of the nucleus. In many blood smears, pleomorphic thrombocytes were aggregated. Both thrombocyte types stained strongly with PAS and NBE (with and without fluoride; Fig. 7a,b), and in the elongated cells, the reaction was stronger in the areas where the refractive structures had been detected by Romanowsky staining (Table 2).

\section{Discussion}

The morphologic characteristics of erythrocytes from yellow-bellied sliders in this study were similar to those reported in other chelonians (Sypek and Borysenko, 1988; Alleman et al., 1992; Work et al., 1998; Casal and Orós, 2007; Innis et al., 2007; Chung et al., 2009; Chansue et al., 2011; Arizza et al., 2014). It was the biggest blood cell in this species, with a mean area of $176.9 \mu \mathrm{m}^{2}$, very similar to that reported in other chelonian species (Frye, 1991), including sea turtles (Work et al., 1998; Casal and Orós, 2007) and other emydids (Frye, 1991; Innis et al., 2007; Chung et al., 2009; Chansue et al., 2011; Arizza et al., 2014). Immature erythrocytes had the typical morphology described in other reptiles (Alleman et al., 1992; Campbell and Ellis, 2007; Irizarry, 2010; Chansue et al., 2011). The small basophilic intracytoplasmic inclusions observed in some erythrocytes have been described 
previously in other reptiles and are believed to be a normal and physiologic finding in healthy chelonians (Alleman et al., 1992; Work et al., 1998; Campbell and Ellis, 2007; Casal and Orós, 2007; Basile et al., 2011; Chansue et al., 2011). Some authors identified these inclusions as degenerating organelles (Work et al., 1998; Casal et al., 2007; Chung et al., 2009), while others described them as haemoglobin precipitates (Basile et al., 2011). Davis and Holcomb (2008) stated that the development of these inclusions in the painted turtle (Chrysemys picta picta) was associated with the cell maturation process.

The positive reactions for PAS, NBE and ACP in yellow-bellied sliders' erythrocytes were not described before in other chelonians (Work et al., 1998; Casal and Orós, 2007; Chung et al., 2009). The similar shape and intracytoplasmic location suggest that these positive granules correspond to the basophilic inclusions detected after Romanowsky staining.

Based on the results obtained during this study, and according to the ultrastructural characteristics previously published (Hernández et al., 2016), we classified five types of white blood cells in yellow-bellied sliders: heterophils, eosinophils, basophils, lymphocytes and monocytes, similar to those described in members from the family Emydidae (Innis et al., 2007; Chung et al., 2009; Arizza et al., 2014) and in sea turtles (Work et al., 1998; Casal and Orós, 2007).

Light microscopy showed that heterophils from yellowbellied sliders were morphologically similar to those described for other reptiles (Sypek and Borysenko, 1988; Bounous et al., 1996; Campbell and Ellis, 2007; Salakij et al., 2014). This leucocyte was a big sized cell, but its average area $\left(113.2 \mu \mathrm{m}^{2}\right)$ was smaller than the eosinophil area in this species, and similar to those described in other related species (Innis et al., 2007; Chansue et al., 2011; Arizza et al., 2014); however, the heterophil from Asian yellow pond turtles (Ocadia sinensis) was the biggest leucocyte for that species (Chung et al., 2009). The cytochemical pattern of the heterophils from yellow-bellied sliders was different from the cytochemical patterns reported for other reptiles because heterophils stained with all the cytochemical stains except for TB. Heterophils from other freshwater turtles had different enzymes: heterophils from Asian yellow pond turtles stained with PER (Chung et al., 2009); heterophils from black-bellied slider turtles (Chrysemys dorbignih) stained with non-specific esterase, peroxidase and phosphatases (Azevedo and Lunardi, 2003); and heterophils from yellow-headed temple turtles (Hieremys annandalii) stained with peroxidase, SBB, acid and alkaline phosphatases, $\alpha$-naphthyl acetate esterase and PAS (Chansue et al., 2011). Heterophils from green turtles (Chelonia mydas) stained only with NBE and PAS (Work et al., 1998), and heterophils from loggerhead turtles (Caretta caretta) stained with ACP, PER, CAE and SBB and moderately with PAS (Casal and Orós, 2007). The different enzymes present in different chelonian heterophils could indicate different response pathways in the course of acute inflammation.

Eosinophils from yellow-bellied sliders were homogeneous in size, unlike eosinophils from green turtles (Work et al., 1998) and Kemp's Ridley turtles (Lepidochelys kempi; Cannon, 1992), which are large as well as small. Eosinophils were the biggest leucocytes in yellowbellied sliders with an average area of $123.8 \mu \mathrm{m}^{2}$, similar to other chelonians (Casal and Orós, 2007; Innis et al., 2007), but opposed to yellow-headed temple turtles, in which the eosinophil was the smallest granulocyte with a diameter of $10.61 \mu \mathrm{m}$ (Chansue et al., 2011). In our study, eosinophils were stained with ACP, NBE without sodium fluoride, CAE, PAS and moderately with SBB. This cytochemical pattern was different than those described for other members of the family Emydidae, which had peroxidase-positive eosinophils (Azevedo and Lunardi, 2003; Chung et al., 2009; Chansue et al., 2011); however, it was similar to that reported for loggerhead sea turtles, except for the NBE staining (Casal and Orós, 2007)

Basophils were abundant in yellow-bellied slider blood, similar to those described in desert tortoises (Gopherus agassizii; Christopher et al., 1999) and head-started northern red-bellied cooters (Pseudemys rubriventris; Innis et al., 2007), but the opposite of those described in sea turtles (Cannon, 1992; Work et al., 1998; Casal and Orós, 2007). Basophils were the smallest leucocytes in yellowbellied sliders with an average area of $54.39 \mu \mathrm{m}^{2}$. Although basophils from most emydids (Innis et al., 2007; Chung et al., 2009; Chansue et al., 2011) were bigger than those reported in our study, the cytoplasmic and nuclear measurements of this cell in Sicilian pond turtles (Emys trinacris; Arizza et al., 2014) were very close to those observed in our study. Although basophils were morphologically similar to those described in other reptiles (Campbell and Ellis, 2007), their cytochemical pattern was unique among reptile species (Alleman et al., 1992; Work et al., 1998; Martínez-Silvestre et al., 2005; Chung et al., 2009; Casal and Orós, 2007; Chansue et al., 2011).

Small and large lymphocytes from yellow-bellied sliders were morphologically similar to those reported in other reptiles (Sypek and Borysenko, 1988; Irizarry, 2010), and as seen in this investigation, many chelonian species have shown dimension variability in their lymphocytes (Martínez-Silvestre, 1994; Wilkinson, 2004). In our study, lymphocytes from female turtles were significantly bigger than those from males. Arizza et al. (2014) did not report cell size differences between male and female Sicilian 
pond turtles. After Romanowsky staining, small lymphocytes were sometimes difficult to distinguish from pleomorphic thrombocytes, as described in other reptile species (Alleman et al., 1992; Bounous et al., 1996; Irizarry, 2010). Lymphocytes stained strongly with ACP and weakly with NBE, CAE and PAS. This cytochemical pattern was similar to that of yellow-headed temple turtles (Chansue et al., 2011), but different from those of other chelonians (Work et al., 1998; Casal and Orós, 2007; Chung et al., 2009).

Monocytes from yellow-bellied sliders were similar to those described in sea turtles (Work et al., 1998; Casal and Orós, 2007). With an average area of $104.3 \mu \mathrm{m}^{2}$, it was the third leucocyte in size after eosinophils and heterophils, very similar to that described in other chelonian species (Innis et al., 2007; Casal and Orós, 2007; Chung et al., 2009; Arizza et al., 2014; Carrascal-Velásquez et al., 2014). A small percentage of monocytes showed eosinophilic and basophilic dust-like intracytoplasmic granules, making them partially compatible with the description of azurophil given by some authors (Campbell and Ellis, 2007; Strick et al., 2007; Irizarry, 2010). Despite this fact, because the cytochemical pattern for all monocytes both the 'regular' and 'dust-like cytoplasm' cells was the same, both cells were classified as monocytes. Although there are descriptions of azurophils in chelonians (Keller et al., 2004), those were not based on cytochemical studies. When a cytochemical characterization was performed, azurophils were not identified in most chelonians (Cannon, 1992; Work et al., 1998; Casal and Orós, 2007), except for yellow-headed temple turtles (Chansue et al., 2011). Monocytes stained with Romanowsky stain can be misidentified as big lymphocytes, even when working with fresh blood smears to avoid morphological alterations (Work et al., 1998). Although monocytes shared many cytochemical characteristics with lymphocytes, the key to differentiating between them is that the NBE stain with sodium fluoride was inhibited in monocytes. The cytochemical pattern of monocytes from yellow-bellied sliders was very similar to that reported for green turtles (Work et al., 1998).

We considered the two types of thrombocytes identified in our study as different activation stages of the same cell. Light microscopy showed thrombocytes from yellowbellied sliders to be similar to those reported for other reptiles (Campbell and Ellis, 2007). Pleomorphic or rounded cells were found, typically in aggregates, even when using fresh samples; these are believed to be reactive or activated forms that could develop during the blood extraction (Pellizzon et al., 2002; Campbell and Ellis, 2007; Irizarry, 2010) and are the smallest blood cells with an average area of $33.19 \mu \mathrm{m}^{2}$. Standard thrombocytes showed similar shape and size than those described in other emydids (Innis et al., 2007; Carrascal-Velásquez et al., 2014). Sometimes, round and small thrombocytes were difficult to distinguish from small lymphocytes after Romanowsky staining, even though their nuclei had a more clumped chromatin pattern than lymphocytes and also had a less coloured cytoplasm. Unlike lymphocytes, however, thrombocytes only stained with NBE and PAS, as occurs in other reptiles (Work et al., 1998; Alleman et al., 1999; Harr et al., 2001).

In conclusion, this study provides the first cytochemical classification of blood cells of the yellow-bellied slider (Trachemys scripta scripta) and may serve as a useful guideline for clinical settings and further haematological studies of this species.

\section{Acknowledgements}

The authors thank owners who lent the specimens for this study, the veterinarian Minerva Artiles, and the colleagues of the Veterinary Clinic Atlántico (Las Palmas de Gran Canaria) and Veterinary Hospital Benartemi (Vecindario, Las Palmas).

\section{References}

Alleman, A. R., E. R. Jacobson, and R. E. Raskin, 1992: Morphologic and cytochemical characteristics of blood cells from the desert tortoise (Gopherus agassizii). Am. J. Vet. Res. 53, 1645-1651.

Alleman, A. R., E. R. Jacobson, and R. E. Raskin, 1999: Morphologic, cytochemical staining, and ultrastructural characteristics of blood cells from eastern diamondback rattlesnakes (Crotalus adamanteus). Am. J. Vet. Res. 60, 507-514.

Allender, M. C., M. A. Mitchell, T. Torres, J. Sekowska, and E. A. Driskell, 2013: Pathogenicity of frog virus 3-like virus in red-eared slider turles (Trachemys scripta elegans) at two environmental temperatures. J. Comp. Pathol. 149, 356-367.

Arizza, V., D. Russo, F. Marrone, F. Sacco, and M. Arculeo, 2014: Morphological characterization of the blood cells in the endangered Sicilian endemic pond turtle, Emys trinacris (Testudines: Emydidae). Ital. J. Zool. 81, 344-353.

Azevedo, A., and L. O. Lunardi, 2003: Cytochemical characterization of eosinophilic leukocytes circulating in the blood of the turtle (Chrysemys dorbignih). Acta Histochem. 105, 99105.

Basile, F., A. Di Santi, M. Caldora, L. Ferretti, F. Bentivegna, and A. Pica, 2011: Inclusion bodies in loggerhead erythrocytes are associated with unstable haemoglobin and resemble human Heinz bodies. J. Exp. Zool A: Ecol. Gen. Physiol. 315, 416-423.

Bounous, D. I., T. K. Dotson, R. L. Brooks, and E. C. Ramsay, 1996: Cytochemical staining and ultrastructural characteristics of peripheral blood leucocytes from the yellow rat snake 
(Elaphe obsoleta quadrivitatta). Comp. Haematol. Int. 6, 8691.

Boyer, T. H., and D. M. Boyer, 2006: Turtles, tortoises and terrapins. In: Reptile Medicine and Surgery, 2nd edn. (D. R. Mader, ed). St. Louis, MO: Saunders-Elsevier. pp 78-99.

Caballero, T., M. T. Medina, and M. A. Caballero, 1993: Histoquímica de hidratos de carbono o glúcidos. In: Laboratorio de Anatomía Patológica. (R. García del Moral, ed). Madrid: Interamericana McGraw Hill. pp 241-242.

Campbell, T., and C. Ellis, 2007: Hematology of reptiles. In: Avian and Exotic Animal Hematology and Cytology, 3rd edn. (T. W. Campbell and C. Ellis, eds). Ames, IA: Blackwell Publising Ltd. pp 51-82.

Cannon, M. S., 1992: The morphology and cytochemistry of the blood leukocytes of Kemp's Ridley sea turtle (Lepidochelys kempi). Can. J. Zool. 70, 1336-1340.

Carrascal-Velásquez, J., H. Negrete-Cartagena, C. RojanoBolaño, G. Álvarez-Otero, J. Chacón-Pacheco, and J. Linares-Arias, 2014: Caracterización hematológica de hicoteas (Trachemys callirostris. Gray, 1856) en Córdoba, Colombia. Rev. Med. Vet. 28, 43-55.

Casal, A. B., and J. Orós, 2007: Morphologic and cytochemical characteristics of blood cells of juvenile loggerhead sea turtles (Caretta caretta). Res. Vet. Sci. 82, 158-165.

Casal, A. B., F. Freire, G. Bautista-Harris, A. Arencibia, and J. Orós, 2007: Ultraestructural characteristics of blood cells of juvenile loggerhead sea turtle (Caretta caretta). Anat. Histol. Embryol. 36, 332-335.

Chansue, N., A. Sailasuta, J. Tangtrongpiros, S. Wangnaitham, and N. Assawawongkasem, 2011: Hematology and clinical chemistry of adult yellow-headed temple turtles (Hieremys annandalii) in Thailand. Vet. Clin. Pathol. 40, 174-184.

Christopher, M. M., K. H. Berry, I. R. Wallis, K. A. Nagy, B. T. Henen, and C. C. Peterson, 1999: Reference intervals and physiologic alterations in hematologic and biochemical values of free ranging desert tortoises in the Mojave Desert. J. Wildl. Dis. 35, 212-238.

Chung, C. S., C. H. Cheng, S. C. Chin, A. H. Lee, and C. H. Chi, 2009: Morphologic and cytochemical characteristics of Asian yellow pond turtle (Ocadia sinensis) blood cells and their hematologic and plasma biochemical reference values. J. Zoo Wildl. Med. 40, 76-85.

Davis, A., and K. Holcomb, 2008: Intraerythrocytic inclusion bodies in painted turtles (Chrysemys picta picta) with measurements of affected cells. Comp. Clin. Pathol. 17, 51-54.

Ernst, C. H., and R. W. Barbour, 1989: Turtles of the World. Washington DC: Smithsonian Institution Press.

Frank, N., and E. Ramus, 1995: A Complete Guide to Common Names of Reptiles and Amphibians of the World. Pottsville, PA: NG. Publishing Inc.

Fritz, U., and P. Havas, 2007: Cheklist of chelonias of the world. Vertebr. Zool. 57, 149-368.

Frye, F. L., 1991: Hematology as applied to clinical reptile medicine. In: Biochemical and Surgical Aspects of Captive
Reptile Husbandry, Vol. I, Second Enlarged edn. (F. L. Frye, ed). Malabar, FL: Krieger Publishing Company. pp 209-279.

Guirlet, E., and K. Das, 2012: Cadmium toxicokinetics and bioaccumulation in turtles: trophic exposure of Trachemys scripta elegans. Ecotoxicology. 21, 18-26.

Harr, K. E., A. R. Alleman, P. M. Dennis, L. K. Maxwell, B. A. Lock, R. A. Bennett, and E. R. Jacobson, 2001: Morphologic and cytochemical characteristics of blood cells and hematologic and plasma biochemical reference ranges in green iguanas. J. Am. Vet. Med. Assoc. 218, 915-921.

Hernández, J. D., J. Orós, M. Artiles, P. Castro, and A. Blanco, 2016: Ultrastructural characteristics of blood cells in the yellow-bellied slider turtle (Trachemys scripta scripta). Vet. Clin. Pathol. 45, 106-109.

Innis, C. H. F., M. Tlusty, and D. Wunn, 2007: Hematologic and plasma biochemical analysis of juvenile head-started northern red-belied cooters (Pseudemys rubriventris). J. Zoo Wildl. Med. 38, 425-432.

Irizarry, A. R., 2010: Hematology of Reptiles. In: Schalm's Veterinary Hematology, 6th edn. (D. J. Weiss and K. J. Wardrop, eds). Ames, IA: Wiley-Blackwell. pp 1004-1012.

IUCN/SSC, 2017: 2017 IUCN Red List of Threatened Species. www.redlist.org. (accessed 14 March 2017).

Joyce, W., and T. Wang, 2014: Adenosinergic regulation of the cardiovascular system in the red-eared slider Trachemys scripta. Comp. Biochem. Physiol. A. 174, 18-22.

Keller, J. M., J. R. Kucklick, M. A. Stamper, C. A. Harms, and P. McClellan-Green, 2004: Associations between organochlorine contaminant concentrations and clinical health parameters in loggerhead sea turtles from North Carolina, USA. Environ. Health Persp. 112, 1074-1079.

Kitana, N., and I. P. Callard, 2014: Effect of cadmium on gonadal development in freshwater turtle (Trachemys scripta, Chrysemys picta). J. Environ. Sci. Health A. 43, 262-271.

Krivoruchko, A., and K. B. Storey, 2013: Anoxia-responsive regulation of the Fox0 transcription factors in freshwater turtles, Trachemys scripta elegans. Biochim. Biophys. Acta. 1830, 4990-4998.

Laird, N. M., and J. H. Wäre, 1982: Random-effects models for longitudinal data. Biometrics. 38, 963-974.

Li, F., Z. Yang, Y. Lu, Y. Wei, J. Wang, D. Yin, and R. He, 2010: Malondialdehyde suppresses cerebral function by breaking homeostasis between excitation and inhibition in turtle Trachemys scripta. PLoS ONE. 5, e15325.

López-Olvera, J. R., J. Montané, I. Marco, A. Martínez-Silvestre, J. Soler, and S. Lavín, 2003: Effect of venipuncture site on hematologic and serum biochemical parameters in marginated tortoise (Testudo marginata). J. Wildl. Dis. 39, 830836.

Mans, C., L. L. Lahner, B. B. Baker, S. M. Johnson, and K. K. Sladky, 2012: Antinociceptive efficacy of buprenorphine and hydromorphone in red-eared slider turtles (Trachemys scripta elegans). J. Zoo Wildl. Med. 43, 662-665.

Martínez-Silvestre, A., 1994: Manual Clínico de Reptiles. Barcelona: Grass-Iatros Ediciones. 
Martínez-Silvestre, A., I. Marco, M. A. Rodríguez-Domínguez, S. Lavín, and R. Cuenca, 2005: Morphology, cytochemical staining and ultrastructural characteristics of the blood cells of the giant lizard of El Hierro (Gallotia simonyi). Res. Vet. Sci. 78, 127-134.

Muro, J., R. Cuenca, J. Pastor, L. Viñas, and S. Lavín, 1998: Effects of lithium heparin and tripotassium EDTA on hematologic values of Hermann's tortoises (Testudo hermanni). J. Zoo Wildl. Med. 29, 40-44.

Pellizzon, C. H., A. Azevedo, L. Casaletti, and L. O. Lunardi, 2002: The thrombocyte aggregation process in the turtle Phrynopys hilarii (Chelonia). An ultrastructural study. J. Submicrosc. Cytol. Pathol. 34, 323-327.

Salakij, C., J. Salakij, S. Apibal, N.-A. Narkkong, L. Chanhome, and N. Rochanapat, 2002: Hematology, morphology, cytochemical staining, and ultrastructural characteristics of blood cells in king cobras (Ophiophagus hannah). Vet. Clin. Pathol. 31, 116-126.

Salakij, C., J. Salakij, K. Prihirunkit, N. A. Narkkong, P. Sanyathitiseree, and K. Kranjanapitukkul, 2014: Quantitative and qualitative morphologic, cytochemical, and ultrastructural characteristics of blood cells in captive Asian water monitors. Vet. Clin. Pathol. 43, 538-546.

Strick, N. I., A. R. Alleman, and K. E. Harr, 2007: Inflammatory cells. In: Infectious Diseases and Pathology of Reptiles. (E. R. Jacobson, ed). Boca Raton, FL: CRC Press. pp 167218.

Sypek, J., and M. Borysenko, 1988: Reptiles. In: Vertebrate Blood Cells. (A. F. Rowley and N. A. Rateliffe, eds). Cambridge: Cambridge University Press. pp 211-256.

Vives, J. L., and J. L. Aguilar, 1988: Métodos citoquímicos y otros procedimientos generales de estudio leucocitario. In: Manual de Técnicas de Laboratorio en Hematología. (J. L. Vives and J. L. Aguilar, eds). Barcelona: Salvat. pp 141-158.

Wilkinson, R., 2004: Clinical pathology. In: Medicine and Surgery of Tortoises and Turtles. (S. McArthur, R. Wilkinson and J. Meyer, eds). Ames, IA: Blackwell Publishing. pp 141-186.

Work, T. M., R. E. Raskin, G. H. Balazs, and S. D. Whittaker, 1998: Morphologic and cytochemical characteristics of blood cells from Hawaiian green turtles. Am. J. Vet. Res. 59, 1252-1257. 